帝人(株)/専務取締役・フィルム事業本部長・研究部門長 風間 清司

諸君は, これから半世紀にわたって, 今後の日本 の成長を支え, 積極的に担い, やがて次の世代にそ の役を引渡していく任務に就くことになる。世界は ますますボーダーレス化が進んでいくので，もっと 大きな舞台で活躍される方も多かろう。

これからの世界は, 現在 54 億 8 千万という人口 が, 50 年後には 100 億近くになろうかという人口 爆発の中で，限りある資源を共通の資産として分け 合いながら一方では地球環境をもうこれ以上破壊す ることなく, 全人類が共生していける国際社会を築 くことができるのかという，目も眩むような大きな 課題を抱えている，2極体制が崩れたいま，民族・ 宗教・南北の対立から世界は逆にむしろ多極化の方 向に動いている今日この頃ではあるが，なんとか人 類の警智で国境のない地球をつくりあげるよう国際 政治に頑張ってもらいたいものである.

一方, 資源活用, 食糧増産, 地球環境保全という ことになれば，これは科学技術の出番であって，化 学者を志す諸君にとって地球世界に貢献できる誠に 心弾む夕ーゲットであるとともに使命ではなかろう か. 数年前の経済過熱のバブルの時代，すぐれた理 学系・工学系の学生たちが先を争って銀行・証券業 界にながれる心佗しい現象があったが，せっかく理 工系を志したからにはこの分野で力の限りを尽くし 地球世界に貢献できる業績を残してもらいたいもの だと思う。

高分子化学は, 戦後 50 年近くの間に質・量ともに 素晴らしい発展をとげ，われわれを取り巻く環境の あらゆる場面に入り込み，われわれの生活を豊かに してくれてきたが, 資源・環境問題に取り組んで全 人類の共生を可能にしていくというこれからの大き な目標を達成するために高分子化学の担うべき役割 は他に類を見ない広がりがあるように思う。そし て，その広がりをさらに大きくしていくためには高 分子化学の枠にとらわ机るとなく, 化学一般に加 えて他分野の科学にも目を配っていくことが大切だ と思う。
人間とは扔かしなもので高々 2 年とか 4 年とかの 期間（博士課程は除いた）に大学で勉強した専門を 自分の一生の専門としその埒外に出ようとしない人 が多い. 入社してから以後の期間のほうが遙かに長 いのにもかかわらずにである，若いときはそれだけ 頭が柔軟で鮮烈な印象を残すのだということでもあ ろうが，いかにも勿体ない話である。科学・技術の 進展は学際・業際分野に現れることが多いので, 自 分の専門を座標軸の原点に据えておくことは大切だ が，情報の氾濫する現在の環境を生かして幅を広げ ていく努力が極めて大切であると考える.

最後に，企業ないしは事業の寿命について述べた い.

このたび，緑あってそれぞれに選び選ばれて入社 された諸君，企業は永遠だとまでは思っていないに しても相当に長期にわたって安定に存在し続けるも のだと思っていないだろうか. 10 年前によく読ま れた『エクセレント・カンパニー』のその後に思い を至すまでもなく企業の盛衰は意外に激しいものが ある. 最近の例では電算機 MF の大メーカーの幾 つかがダウンサイジングへの潮流のなかで苦境に立 っていると伝えられている。

私のみるところでは, 一つの事業の寿命はほぼ 20 年程度のものである. 幾つもの企業が 30 年, 50 年, 100 年にわたって存続し続けているのは，それ らの企業の中で, 事業の延命を図るべく研究・開 発・生産部門の協力のもとに他社に先駆けた涙ぐま しい努力の行われた賜物であり，場合によっては時 代・環境の変化を先取りして, 新しい事業を育てて は積極的にのりかえてきた結果にほかならない。

諸君は, 社歷 40 年の間に平均して 2 度のこうし た変化に遭遇することになる。願わくば，受動的に ではなく能動的にこの変化をつくりだす側となって 社業に貢献すると共に, 半世紀後の地球世界の平和 な共生に役立つ業績を残して戴きたいものである。

\section{Kiyoshi Kazama}


新入生, 新人社員の皆さん, 御入学, 御入社おめ でとう。経済環境の厳しい中，大きな不安を抱きな がらの入学, 入社に, 厳しい時期のスタートはきっ と皆さんが鍛えられてたくましく成長するのに役に 立つと思う。

企業において永年，高分子複合材料の研究・開発 に携り，現在は事業部で開発成果の事業化に取り組 んでいる筆者の立場から，ここでは特に企業に入社

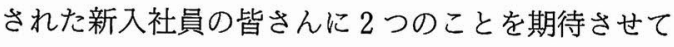
いただく。

1. 大きなスケールで考えて，あせらずに

高分子の展開を例えば図のように大まかに把えて みると，高分子はこれから大きな転換期を迎えそう な気配を感じる。

皆さんはこんな状況の中でこれから企業の一員と してスタートされるわけである.今までのやり方の 延長でやれることは知識も経験も豊富な先輩達がこ れからもリードしてそれなりに答を出してくれると 思う。今までとは質的に明らかに異なること（例え

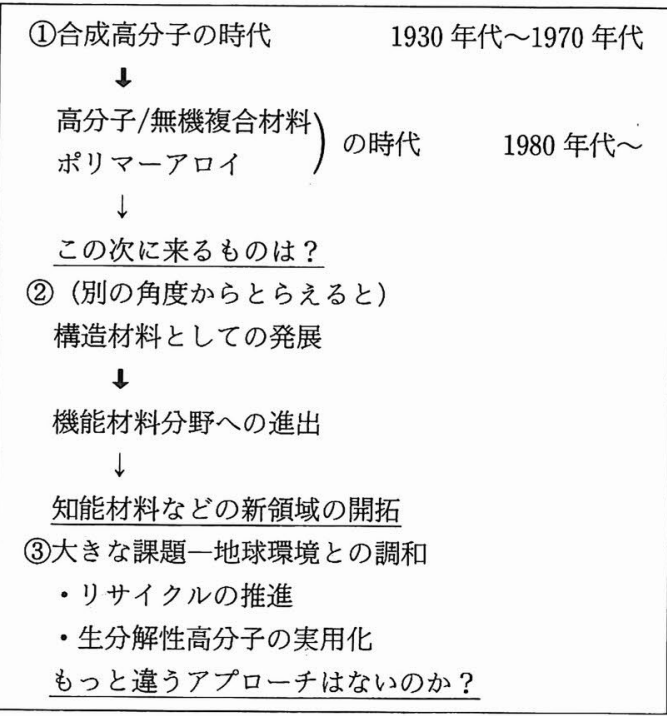

図 高分子の展開概観
ば図でアンダーラインを施した部分）にどう対応す るかについては，次代を担うべき皆さんがいずれ中 心になって取り組んでいく課題だと筆者は考える。

皆さんには, 一方で石器, 青銅器に始まる材料の 歴史と来るべき新しい世紀以降の未来を頭においた 長い時間のスケールをもち，一方で地球，宇宙の規 模で材料の循環や影響を考光る空間のスケールをも って，高分子のこれからの大きな課題にあせらずに じっくりと取り組んでいただきたい。

\section{2. 人間にいつも興味と関心を}

皆さんの多くは理科系の出身で, 研究・開発など の技術系の仕事につかれると思う。そんな皆さんの 社会人としてのスタートに当り「人間にいつも興味 と関心をもつ」ことを勧める。

アカデミックの世界では, 自分のあるいは自分達 の発見, 発明はそれだけで完結して価值があるが, 企業においては研究や開発はそれ自体では価值を生 み出さない.

研究・開発する $\longrightarrow$ 製造する 使う

という流れがあって，どの工程も機械やコンピュー 夕が使われるにしても, 結局は人間の行為の積み重 ねである。研究・開発する人の仕事が成果となって 完結するためには多くの人達の行為の集結が必要で ある.ですから研究・開発部門の人達は自分の研 究・開発対象の物質に対するのと同等以上に行為の 主体である人間に対して興味と関心をもつ必要があ る.

これから研究・開発に携る皆さんは，企業の中の 製造，営業などの他部門，市場のユーザーなど，違 う分野の人達との密接な人間的交流を仕事の原点と するようにぜひ心掛けていただきたいと思う。

Hiroshi Yui (専門=高分子複合材料) 
ここ数年の世界の激変振りには驚嘆する。ベルリ ンの壁の崩壞, ソ連社会主義の崩壊, 民族主義の台 頭, 湾岸戦争, 宗教対立等々, 枚挙に暇がない.こ のような時期にあってわが日本は経済大国としてま すます発展しつつあり，本来なら゙ば喜ばしいことな のに，世界の国々から非難される状況にあるのは何 とも言いようのない矛盾を感ぜざるを得ない. しか し，ここでわれわれは真面目に世界の中の日本を考 える必要がある。

戦後の荒廃から立直る機会を与えられ, 勤勉かつ 実直に復興に当った結果として現在の繁栄があるの は世界の認めるところである。その間にフルブライ 卜奨学生等, 若き学徒に与えられた海外留学のチャ ンスは狭い日本を離れ広い視野を培うのにどれほど 役立ったかはいうまでもない. また，欧米から先端 技術をいち早く輸入し, 日本流に焼き直して独自の 技術に発展させ生産性を高めたことが技術立国とし ての日本を築き上げた，これらの恩義を “恩義” と して認識している人々がどのくらいいるだろうか. アメリカ，ソ連が超大国としての権威を失墜し，ヨ 一ロッパ諸国も種々の社会情勢変化に疲弊している 今日, 日本は少し傲慢になってはいないだろうか。 大いに反省すべき点である。

今の日本にできる “恩返し”は, フルブライトの 日本版で海外からの留学生を受け入れ先端科学技術 を伝授すると共に，多くの研究者を招聘して共同研 究を展開することである。最近は政府レベル，民間 レベルのいずれでもこのような傾向が見られ始めた ことは素晴らしいが, 新たな問題も生じ始めてい る. 生活樣式の相違, 住宅問題, 家族の活動 (通学 を含めて）等である．住宅問題のように一個人では 対応の仕椂のないものもあるが，多くの問題は周辺 の人々の個人的な接し方で解決できるものである.

前置きが長くなったが，これからの若い人々に対 する提言として, 公私共に国際感覚を豊かに発揮で きる環境を作り上げて欲しい。本人が国際化の重要 性を認識することが基本であり，英語でコミュニケ
ートすることを厭わない，積極的に外人に接する， など日々の生活において国際感覚を養うことは簡単 である．日本の教育では中学から英語の授業がある が大学生, 社会人になっても英会話のできない人は 極めて多い. 英語教育が間違っているのは当然だ が，だからといってそのまま放置して英会話嫌いに なっては困る。英会話の初歩を習って（月謝を払っ て), 英語のコミュニティ作りをする必要がある。 ただし，英会話ができても国際感覚は簡単には身に 付かない. 相手の国を歴史的, 文化的, 政治的に理 解しておかないと, 折角の好意が逆に反感を買うこ とになりかねない。特に，前に述べた日本人の“傲 慢さ”が見え隠れするような言動, 態度は謹しまね ばならない。

英会話に慣れる方法の一つとして，ビデオの映画 を薦める。もちろん, 字幕のないものである.シュ ワルツネッガーの “ターミネーター2”であろうと ケビン・コスナーの “JFK”であろうと何でもよい. 分かっても分からなくても何度も見ているうちにそ れとなく理解できるようになる。どうしても分から ない処は後で他の人に聞けばよい. 映画の中にはそ の国の本質が描かれている場合が多いから，一つを 充分に理解すればいろいろな背景がつかめる。映画 とか車, 税金, 選挙の話題は外国人と話をする際に は極めて恰好な話題である。

いつまで英語が世界共通語として通用するかは誰 にも分からないが, 少なくとも 21 世紀の初頭では 未だ英語の力は強いであろう. 堂々と英語で議論で きる人，国際的に通用する人に成長して欲しい.

Hiroyuki Sasabe（専門=分子素子・バイオ素子） 